\title{
Editorial: Voting From Abroad
}

\author{
Johanna Peltoniemi ${ }^{1 *}$, Irina Ciornei ${ }^{2}$ and Staffan Himmelroos ${ }^{1}$ \\ ${ }^{1}$ University of Helsinki, Helsinki, Finland, ${ }^{2}$ Institut Barcelona d'Estudis Internacionals, Barcelona, Spain
}

Keywords: emigrant, homeland elections, political representation, voting abroad, non-resident citizen

\section{Editorial on the Research Topic}

\section{Voting From Abroad}

The questions of emigrant political participation and political representation are increasingly relevant. As Kapur (2014) rightly points out, "the history of humanity, starting from its antecedents in Africa, is a history of migration." However, migrants maintaining ties to various places, creating new patterns of belonging is a more recent phenomena, linked with technological advancements and faster movements of global migration. Globalisation and European integration have led to an increased personal mobility across national borders, which in turn has highlighted questions about national belonging (Aksel, 2014). The traditional assumption of domestic politics to be exclusively decided within the borders of the nation state is also challenged by the notion that communities have extended beyond state boundaries (Dahlin and Hironaka, 2008).

This is exemplified by the fact that the number of countries having adopted policies which allow non-resident citizens to take part in homeland elections from abroad has increased greatly in the last few decades. Currently, around 130 countries allow voting from abroad (see e.g., Lafleur, 2013; Himmelroos and Peltoniemi, 2021). While the conditions for the exercise of external electoral rights, the degree to which these rights are exercised, and the relative weights of emigrants in the national polity vary widely, the trend is nonetheless clear. External voting rights are on the rise throughout democratic and non-democratic regimes. The trend reflects both the extent of emigration and the greater awareness that emigrants maintain ties with their countries of origin.

While emigrant voting rights are viewed by some as an important part of the wave of suffrage reforms, for others they are a contested development that rupture the essence of democracy by breaking the link between citizenship and residence (Reidy). In this Research Topic, Umpierrez de Reguero et al. analyze the nexus between political regimes and external voting rights. Interesting mechanisms are revealed: In democracies with a relatively large diaspora size, emigrant enfranchisement is neither broadcasted nor implemented. On the other hand, the autocracies illustrate that when the diaspora favors the incumbency, external voting rights are extended; otherwise, they are withheld or limited for non-resident citizens. Ireland is a model example of a democratic country with a large diaspora size. In this Research Topic, Reidy connects insights from the emigrant voting literature with historical institutionalism to argue that the longstanding avoidance of emigrant enfranchisement in the Republic of Ireland was overcome during the Great Recession because of an economic imperative, the need for greater investment from the emigrant community. Reidy mirrors the political factors to the economic and administrative viability and finds that diaspora campaigners explicitly link economic engagement with political rights.

However, even after non-resident voters are provided with external voting rights, many open questions remain. Is anyone representing non-resident citizens in the legislative process? What are the added costs of voting? External voting rights do not merely include the institutional side, i.e., having certain rights and duties associated with the institutional belonging, manifested in citizenship law. As the six articles included in this Research Topic demonstrate, the electoral rights are, while essential, only the first piece of the puzzle to enfranchise non-resident citizens. If electoral rights are expected to be something more than a symbolic gesture, both the representativeness of the 
external electorate and the convenience of voting need to be considered. External voting rights are concrete only if nonresident voters have genuine possibilities to participate, costs of voting are diminished to minimum, voting is not only symbolic, but non-resident voters are represented in the legislative process and trust the political and state institutions. Drawing from Pitkin's (1967) theoretical work, Makkonen explores non-resident Finnish citizens' political representation. In their research report, Makkonen asks if there are any MPs like the external voters (descriptive representation) or if someone is acting for the expatriate Finns (substantive representation). In their article, Vento analyzes the political trust of migrants and residents by comparing the trust in Finnish political and state institutions of emigrated Swedish-speaking Finns, and Swedishspeaking Finns living in Finland. Vento presents intriguing results which show that emigrants have on average significantly higher homeland political trust, than those living in Finland. While it is not surprising that citizens emigrating from a Nordic welfare state would have high opinions of the welfare system in their homeland, it is worth noting that the vast majority of the emigrated Swedish-speaking Finns live in other Nordic welfare states and other countries with highly developed welfare services.

Two articles in this Research Topic draw empirical data from the Finnish elections in 2019, as postal voting was for the first time introduced for voters residing abroad. Wass et al. study the experiences from the postal voting in 2019 parliamentary elections in Finland. They suggest that whereas trust in the integrity of postal voting was quite high, various efforts needed from individual voters substantially increased the costs

\section{REFERENCES}

Aksel, D. B. (2014). Kins, Distant Workers, Diasporas: Constructing Turkey's Transnational Members Abroad. Turkish Stud. 15 (2), 195-219. doi:10.1080/ 14683849.2014 .926233

Dahlin, E. C., and Hironaka, A. (2008). Citizenship Beyond Borders: A Cross-National Study of Dual Citizenship*. Sociol. Inq. 78 (1), 54-73. doi:10.1111/j.1475-682X.2008.00221.x

Himmelroos, S., and Peltoniemi, J. (2021). External Voting Rights from a Citizen Perspective - Comparing Resident and Non-Resident Citizens' Attitudes Towards External Voting. Scand. Polit. Stud. 44 (4), 463-486. doi:10.1111/1467-9477.12211

Kapur, D. (2014). Political Effects of International Migration. Annu. Rev. Polit. Sci. 17 (1), 479-502. doi:10.1146/annurev-polisci-043010-095807

Lafleur, J.-M. (2013). Transnational Politics and the State: The External Voting Rights of Diasporas. Abingdon: Routledge.

Pitkin, H. F. (1967). The Concept of Representation. Los Angeles: University of California Press. of postal voting. These themes are further studied as Weide explores the introduction of the postal vote from the grassroots perspective. Weide studies how safeguarding ballot secrecy was resolved in Finland in the policy implementation by the witness requirement, and how the individual voters subsequently applied it. Weide finds that according to the voters' accounts of the act of voting, the adopted method for underlining the importance of ballot secrecy in the Finnish overseas postal voting system made little sense for many voters. While they effectively practice ballot secrecy, many voters fail to demonstrate this to the witnesses they were supposed to convince.

Whereas the field of transnational electoral studies is still relatively novel, the increased cross-border mobility and supranational political engagement have added a new layer of complexity to individual experiences. With more citizens living and working outside of their home country and new technologies making it ever easier for emigrants to participate in the homeland politics, the topic of emigrant voting is highly relevant. Whereas the first step of external voting rights is the actual legal right to participate, the enfranchisement, it is not the only factor in external voting rights. Both representativeness in the legislative process and convenience of voting are essential for political inclusion and crucial when evaluating the success of enfranchisement.

\section{AUTHOR CONTRIBUTIONS}

All authors listed have made a substantial, direct, and intellectual contribution to the work and approved it for publication.

Conflict of Interest: The authors declare that the research was conducted in the absence of any commercial or financial relationships that could be construed as a potential conflict of interest.

Publisher's Note: All claims expressed in this article are solely those of the authors and do not necessarily represent those of their affiliated organizations, or those of the publisher, the editors and the reviewers. Any product that may be evaluated in this article, or claim that may be made by its manufacturer, is not guaranteed or endorsed by the publisher.

Copyright (C) 2022 Peltoniemi, Ciornei and Himmelroos. This is an open-access article distributed under the terms of the Creative Commons Attribution License (CC $B Y)$. The use, distribution or reproduction in other forums is permitted, provided the original author(s) and the copyright owner(s) are credited and that the original publication in this journal is cited, in accordance with accepted academic practice. No use, distribution or reproduction is permitted which does not comply with these terms. 